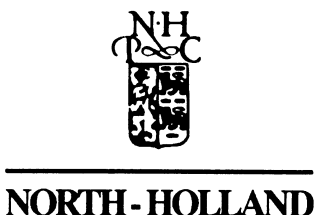

NORTH-HOLLAND
North American Journal of Economics and Finance 11 (2000) 137-151
THE NORTH AMERICAN

JOURNAL OF

ECONOMICS

AND FINANCE

\title{
A framework for stabilizing the euro/yen/dollar triplet
}

\author{
Peter Bofinger* \\ Bayerische Julius-Maximilians-Universität Würzburg and CEPR, Sanderring 2, D-97070, Würzburg, Germany
}

Received 1 July 2000; received in revised form 1 September 2000; accepted 1 September 2000

\begin{abstract}
The current debate on exchange rate regimes is shaped by the so-called inconsistency triangle. In this paper I show that the discussion has overlooked a "third way" which combines capital mobility with monetary policy autonomy, and an exchange rate path determined by interest rate differentials. My scheme relies on interventions that are always carried out by the central bank with the strong currency, and a full sterilization of interventions with the instrument of a deposit facility. Thus the G3 central banks could set a band for their bilateral exchange rates with the floor and the ceiling defended by the respective strong central bank. As exchange rates bands are adjusted according to short-term interest rate differentials, there are no sterilization costs for the intervening central bank. Over the medium and long run interest rates are mainly determined by inflation differentials. Thus, the exchange rate band would follow a PPP path. (C) 2000 Elsevier Science Inc. All rights reserved.
\end{abstract}

JEL classification: E5; F41; F42

Keywords: Exchange rate systems; Interventions; Monetary policy

\section{Introduction}

With the continuing instability of the exchange rates between the three key currencies of the international monetary system there is a growing academic interest in the possibilities of limiting such fluctuations with interventions or even formal exchange rate arrangements (Williamson, 1999; Clarida, 1999; International Monetary Fund, 2000; Schwartz, 2000). A main objection against all proposals which aim at stabilizing exchange rates derives from the

* Tel.: +49-931-312-945; fax +49-931-312-775.

E-mail address: Bofinger@t-online.de (P. Bofinger). 
so-called inconsistency triangle. It maintains that stable exchange rates reduce the effectiveness of domestic monetary policy. In addition, it is often argued that because of the huge size of foreign exchange markets central banks with a limited amount of foreign exchange reserves are unable to defend a fixed rate against prolonged market pressure.

In this paper, I show that both arguments are flawed. The second argument does not differentiate between interventions made by a central bank with a weak and a central bank with a strong currency. The first argument overlooks a "third way" between freely flexible and completely fixed exchange rates. I will argue that, under certain conditions, the central banks of the G3 (the Federal Reserve, the Bank of Japan and the European Central Bank) are able to pursue domestically-oriented interest rate policies and at the same time target bilateral exchange rate paths that are determined by interest rate differentials.

It is shown that under these conditions the inconsistency triangle can be converted into a consistency triangle, which provides an additional degree of freedom to policymakers in the G3 central banks. This approach may help avoid future misalignments, that is, discrepancies between current and equilibrium levels of exchange rates.

The main focus of the paper is on the interplay of exchange market intervention and monetary policy. Thus, it skirts the more fundamental question of whether it is desirable at all to limit market-determined exchange rate paths by central bank intervention. But it is based on the recognition that market determined rates can deviate substantially from the levels that are compatible with macroeconomic equilibrium in the G3 economies. ${ }^{1}$ It also assumes that central banks and international institutions may have greater interest and hence comparative advantage in identifying "equilibrium" or long run exchange rates, while foreign exchange markets often pursue objectives that are more short-run in nature. The paper makes no attempt, however, to define equilibrium exchange rates (Wren-Lewis, 1998; Isard \& Faruqee, 1998).

\section{The size of foreign exchange markets}

To many observers it is the sheer size of foreign exchange markets that would prevent any systematic management of exchange rates-even by the central bank of a large currency area. $^{2}$ According to the Bank for International Settlements (1999, p. 117), in 1998 the

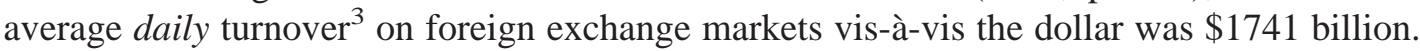
Even allowing for considerable double counting, the figures look impressive. Compared with the gold and foreign exchange reserves of all central banks in the world, which total almost the same amount (dollar 1746 billion in 1999; Bank for International Settlements, 2000, p. 86), the fire power of official interventions seems very limited.

But for a clear understanding of these turnover rates, it is important to know how foreign exchange markets are organized. One of the most important features is the "market-maker" principle, ${ }^{4}$ which means that all participants of the interbank foreign exchange market are ready to quote a bid and a ask rate for a currency and thus are ready to buy and sell at any moment, irrespective of whether they are actually in need of additional positions in a currency. As each participant is able to get rid of an unwanted position immediately by contacting another market maker, the risk associated with being a market maker is very 


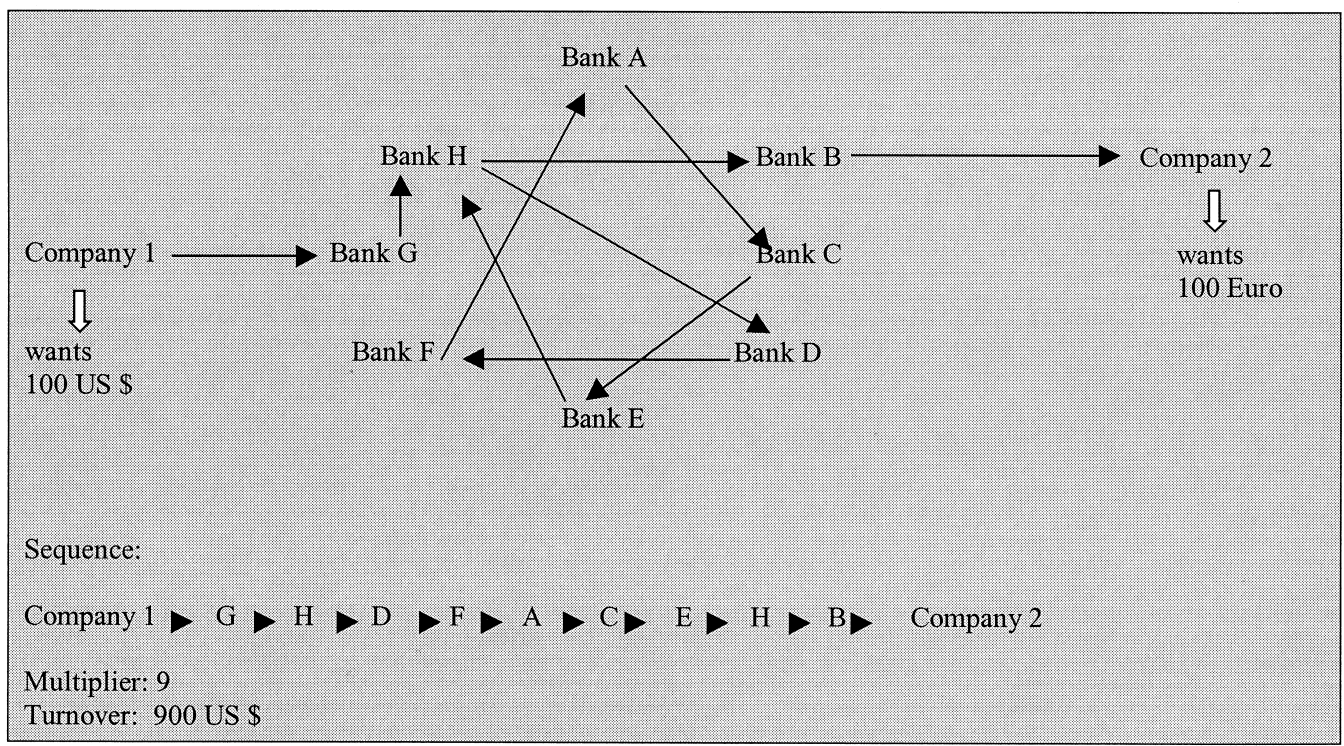

Fig. 1. Market maker principle.

limited. This organization of the foreign exchange market has the effect of magnifying total turnover. As Fig. 1 shows, an initial order by a German firm to sell 100 euros for dollars can generate many intermediate transactions among market makers before it reaches a bank that needs euro deposits for a customer.

Because of the speed with which intermediate transactions are carried out, the multiplier between an outside transaction and internal transactions can be very high. Through the same mechanism, any foreign exchange intervention by a central bank will also have a strong multiplier effect. ${ }^{5}$ Thus, it makes very little sense to compare the stock of foreign exchange reserves with daily turnover on foreign exchange markets.

\section{Two directions of the intervention policy}

Nevertheless, this logic of foreign exchange markets in no way implies that a large central bank like the ECB with foreign exchange reserves (including gold) of about euro 400 billion, cannot run out of reserves. The effectiveness of foreign exchange market intervention depends on the direction in which an intervention is carried out. When a central bank defends its currency against depreciation, that defense takes place under the budget constraint of a given stock of foreign exchange reserves (including existing credit lines with other central banks and international institutions). In such a situation, a central bank is always confronted with the risk that its exchange rate policy will run out of ammunition. Since foreign exchange markets are able to anticipate such a situation, the central bank becomes vulnerable to "speculative attacks" which tend to accelerate the loss of reserves.

The situation is completely different if a central bank tries to limit an appreciation of its 


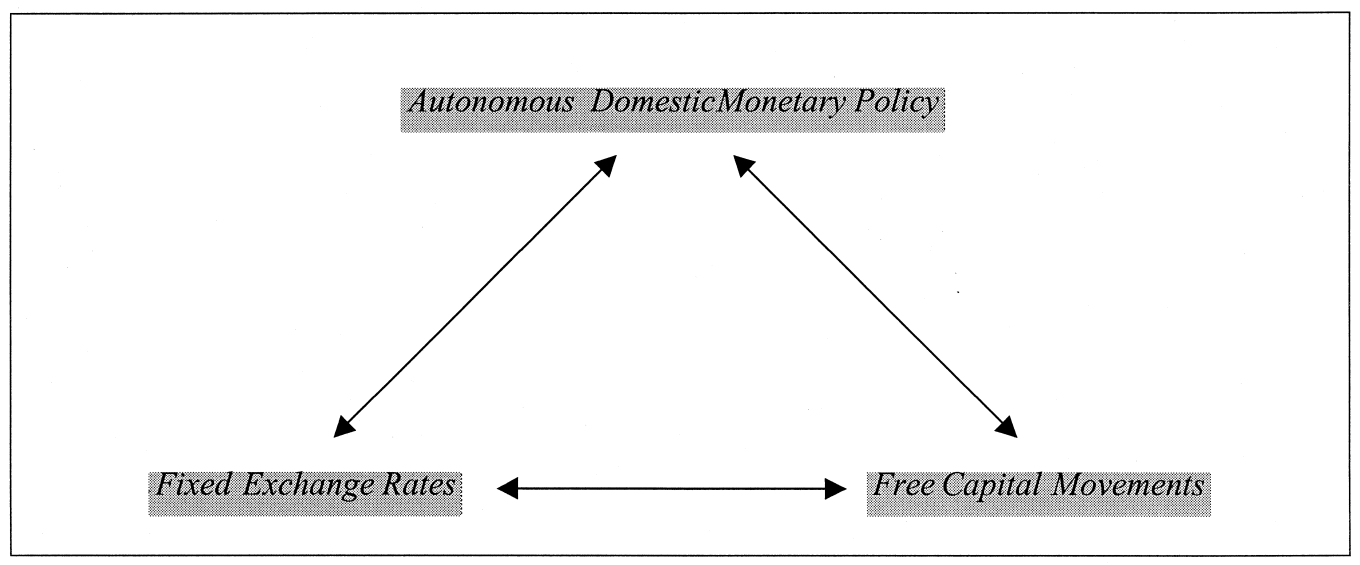

Fig. 2. Inconsistency triangle.

currency. Here, the central bank buys foreign exchange against central bank deposits (denominated in its own currency), which it can supply without quantitative limits. As there exists in principle no hard budget constraint, speculative attacks by the markets are no longer a real threat (Wolf, 1999).

Thus, if one wants to design an international system that is able to cope with strong and persistent speculative attacks, it needs to be built on the central rule that all intervention transactions have to be financed by the central bank with a strong currency. This would imply that the Bank of Japan is responsible for preventing the yen from appreciating vis-à-vis the dollar, while the Federal Reserve would be obliged to stop the depreciation of the euro vis-à-vis the dollar. In fact, in the period from June 1999 to June 2000 the Japanese Ministry of Finance ${ }^{6}$ increased its foreign exchange reserves by $\$ 110$ billion, which helped keep the yen above the 100 yen per dollar threshold.

\section{Foreign exchange market intervention and domestic monetary policy}

The fact that the G3 are able to stabilize exchange rates in a concerted effort financed by member central banks with strong currencies does not mean that such concertation is desirable. To most economists the main disadvantage of any form of exchange rate stabilization is the loss of domestic monetary policy autonomy. In the words of Obstfeld \& Rogoff (1995, p. 75): “The key lesson is that a government that fixes its currency's exchange rate loses control of the domestic money supply." This is the view known as the "inconsistency triangle" (or "impossible trinity"), which means that it is not possible to combine fixed exchange rates with free capital movements and autonomous monetary policy (Fig. 2).

At first sight, this argument sounds very convincing, since interventions on the foreign exchange market have a direct impact on the monetary base (i.e., the sum of commercial banks' reserves with the central bank and currency in circulation). If a central bank buys foreign exchange from a commercial bank, it credits the equivalent in domestic currency to the bank's central bank account. As a result the monetary base increases. 
Table 1A

Simplified central bank balance sheet before sterilized intervention

\begin{tabular}{lllr}
\hline Exchange reserves & 1,000 & Reserves of commercial banks & 500 \\
Credits to domestic commercial banks & 1,000 & Currency in circulation & 1,500 \\
Total & 2,000 & Total & 2,000 \\
\hline
\end{tabular}

If a central bank sells foreign exchange to a commercial bank, it debits the equivalent to the bank's central bank account. As a result the monetary base decreases. Such interventioninduced changes in the monetary base can have far-reaching consequences on the domestic economy of the respective countries. ${ }^{7}$ An attempt to limit an appreciation, for example, would be associated with an increase of the domestic monetary base, which, other things the same, would have inflationary consequences.

\subsection{The mechanics of sterilized interventions}

In the literature, two different definitions of sterilization can be found which depend on the operating target of a central bank. To most economists, sterilization means that a central bank tries to keep the monetary base constant, ${ }^{8}$ which implies that the monetary base is used as the operating target of domestic monetary policy. However, since central banks target short-term interest rates, it makes more sense to define sterilization as a policy that leaves domestic short-term rates unchanged.

In the case of an unwanted increase of the monetary base or an unwanted decline in interest rates, a central bank has to reduce the credits that it offers to commercial banks. In addition, it may have to sell short-term bonds to the banking system or to provide the latter with interest-bearing deposits that cannot be used for domestic credit expansion. A very useful instrument for mopping up excess liquidity is the ECB's "deposit facility." It offers banks an interest-bearing investment for excess liquidity. In the case of massive interventions, which drive the central bank's refinancing credits to zero, the interest rate on the deposit facility will determine domestic money market rates.

In the case of a decrease of the monetary base, a central bank has to provide additional credits to the commercial banks. If it operates with refinancing facilities (such as the ECB's "marginal lending facility"), this adjustment is provided automatically. Here, the interest rate on the marginal lending facility determines the domestic money market rate.

The mechanics of sterilized interventions are shown in Tables 1A and 1B for a very simplified central bank balance sheet. It is assumed that the amount of the interventions (4000) is higher than the credits that the central bank has provided to commercial banks

Table 1B

Simplified central bank balance sheet after sterilized intervention $(4,000)$

\begin{tabular}{lclr}
\hline Exchange reserves & 5,000 & Reserves of commercial banks & 500 \\
Credits to domestic commercial banks & & Currency in circulation & 1,500 \\
Total & & Deposit facility & 3,000 \\
& 5,000 & Total & 5,000 \\
\hline
\end{tabular}




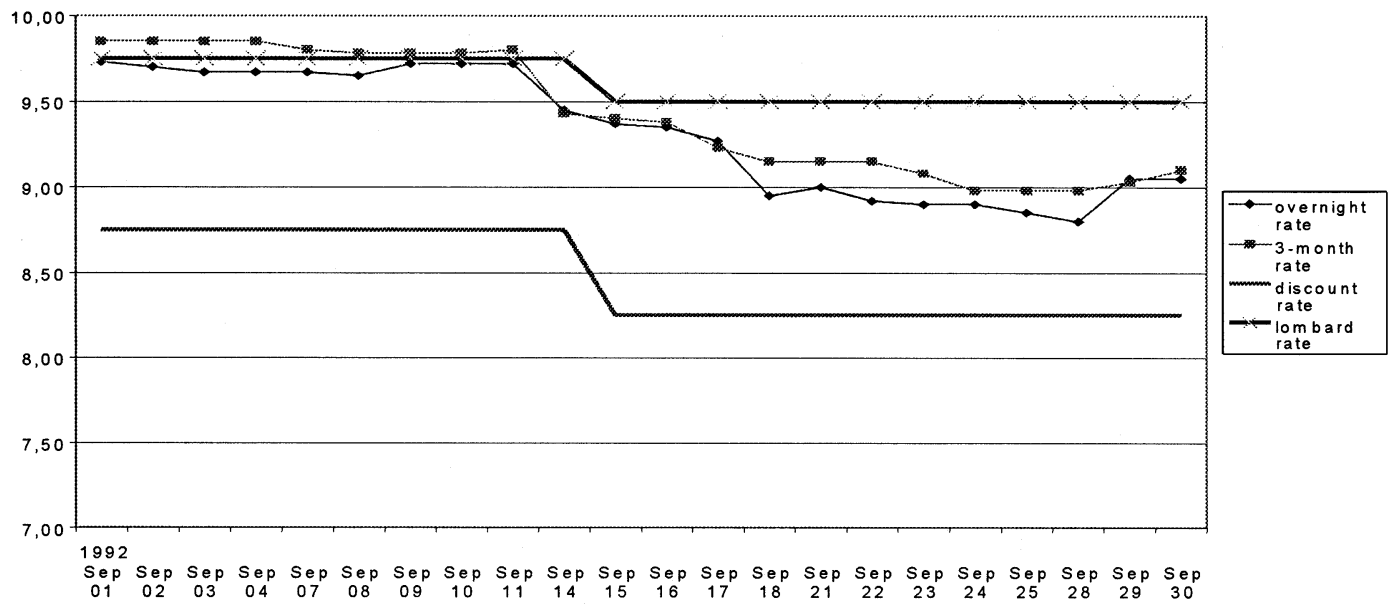

Source: Deutsche Bundesbank

Fig. 3. Short-term DM interest rates during the September 1992 EMS crisis.

(1000). As a result of the sterilization, these credits go to zero and the excess liquidity has to be deposited in the deposit facility. It is important to note that in this case the monetary base and, thus, domestic money market rates remain unchanged.

A good example of a sterilization policy that aims at control of domestic interest rates is provided by the Bundesbank's money market management during the crises of the European Monetary System (EMS) in September 1992. In that month, the Bundesbank bought European currencies equivalent to DM 92.7 billion (Deutsche Bundesbank, 1993a). Nevertheless, as Fig. 3 shows, it was able to keep the daily money market rates within the limits set by its policy rates (Lombard rate and Discount rate). Table 2 shows that this was achieved by a reduction of credits to commercial banks and by an absorption of excess liquidity with foreign currency swaps and short-term notes (column 5). A similarly successful sterilization can be observed in the second EMS crisis in July $1993 .{ }^{10}$

Table 2

Money market management by the Bundesbank in September 1992

\begin{tabular}{llllllr}
\hline Date & $\begin{array}{l}\text { Foreign } \\
\text { exchange } \\
\text { reserves }\end{array}$ & $\begin{array}{l}\text { Credits to } \\
\text { domestic } \\
\text { banks }\end{array}$ & Currency & Reserves & $\begin{array}{l}\text { Other } \\
\text { liabilities } \\
\text { vis-à-vis } \\
\text { domestic banks }\end{array}$ & Sum \\
& $(1)$ & $(2)$ & $(3)$ & $(4)$ & \multicolumn{2}{l}{$(5)(6)=(3)+(4)+(5)$} \\
\hline Aug. 31, 1992 & 101.7 & 224.4 & 199.8 & 98.2 & 1.9 & 299.9 \\
Sept. 7, 1992 & 101.5 & 215.9 & 202.4 & 86.4 & 1.9 & 290.7 \\
Sept. 15, 1992 & 125.1 & 198.8 & 201.1 & 93.7 & 1.9 & 290.7 \\
Sept. 23, 1992 & 169.4 & 168.4 & 199.9 & 65.4 & 24.9 & 328.3 \\
Sept. 30, 1992 & 179 & 166.3 & 201.8 & 90.8 & 35.7 & 293.1 \\
Oct. 7, 1992 & 171.8 & 154.9 & 204.9 & 86.3 & 1.9 & \\
\hline
\end{tabular}

Source: Wochenberichte der Deutschen Bundesbank. 
Thus, one can conclude that each of the three G3 central banks is always able to prevent its own currency from appreciating vis-à-vis the two remaining currencies and at the same time to maintain full control over domestic short-term interest rates:

- Since it is buying assets denominated in the foreign currency and supplying central bank deposits denominated in its own currency, there exists no budget constraint for its interventions.

- With an unlimited deposit facility it can always mop up the excess liquidity that is created by such interventions. The interest rate of the deposit facility enables the central bank to determine money market rates independently of its intervention policy. Since the Federal Reserve and the Bank of Japan do not possess the deposit-facility instrument, their sterilization activities could be limited by the amount of short-term paper they can supply to the market. However, it should not be too difficult to add a deposit facility to the toolbox of monetary policy instruments.

\subsection{The views of the literature}

In contrast to the foregoing argument, the literature comes to a rather skeptical assessment of sterilized interventions. According to Obstfeld and Rogoff (1995, p. 76), "The fact is that for all the fanfare and attention they sometimes receive, sterilized interventions are largely smoke and mirrors. Because they do not change relative money supplies, sterilized interventions can only have modest effects, if any, on interest and exchange rates." 11

To better understand this view, it is necessary to examine sterilized intervention in more detail. Table 3 assumes that the euro/dollar rate is 1 dollar per euro. The starting point is a situation where Deutsche Bank owns a money market deposit at Dresdner Bank of 100 euros. We assume that at the prevailing exchange rate Deutsche Bank wants to change this deposit into a dollar deposit, but that no other commercial bank is willing to supply dollars at this rate. Thus, if it wants to maintain this rate, the Federal Reserve has to intervene. It buys the 100 euros from Deutsche Bank and supplies the latter with a \$100 deposit at Chase Manhattan Bank. As a consequence, the reserves of Chase Manhattan with the Federal Reserve increase by the same amount. In the second stage, the Fed sterilizes the intervention and sells short-term notes to Chase Manhattan. Fig. 3 shows that the main effect of sterilized interventions derives from the willingness of a central bank to increase the supply of its own currency and to reduce the supply of the foreign currency. This implies above all a willingness of the central bank to assume an exchange rate risk.

From Table 3 one can see that sterilization requires neither a change in the monetary bases nor in the money stocks (which are held by nonbanks) of the two currency areas. Thus, the quote by Obstfeld and Rogoff misses the point. The same applies to the argument that sterilized intervention is effective only if foreign and domestic assets are imperfect substitutes and that this cannot be taken as given (Schwartz, 2000). As our example shows, the whole chain of transactions was set in motion because Deutsche Bank wanted to change a euro deposit into a dollar deposit. If it regards both assets as perfect substitutes, there is no need for intervention. 
Table 3

Sterilized interventions and their impact on balance sheets
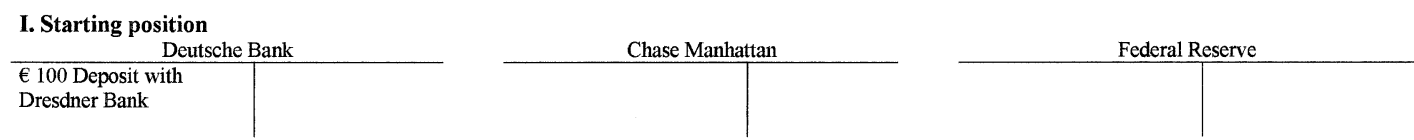

II. Intervention: Federal Reserve buys $€ 100$ from Deutsche Bank

$\frac{\text { Deutsche Bank }}{\text { \$ } 100 \text { Deposit with Chase }}$
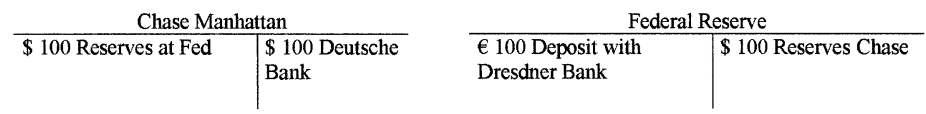

III. Sterilization by the Federal Reserve
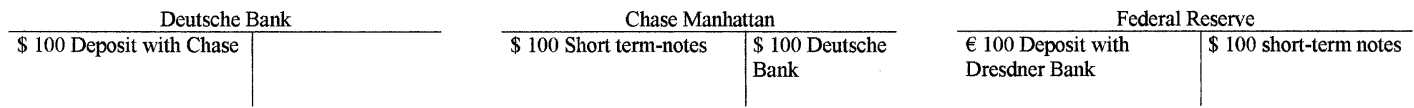

In fact, especially in the more recent literature, a somewhat more positive assessment of sterilized intervention prevails (e.g., Dominguez \& Frankel, 1993; Vitale, 1997; Fatum \& Hutchison, 1999). The observed low effectiveness of sterilized intervention in some episodes can be explained by the specific way in which such interventions were carried out. Instead of publicly announced exchange rate targets, most of these interventions were carried out secretly, so that there was no signaling effect (see below). ${ }^{12}$ As Schwartz (2000) shows, the amount of intervention carried out by the US authorities has always been very limited. ${ }^{13}$ Finally, as noted above, it is important to differentiate interventions made in a situation of depreciation from those involving appreciation of the domestic currency.

As far as the signaling effect of sterilized intervention is concerned, the literature has focused on two variants of this effect. In the view of some authors, sterilized intervention can provide a signal for future changes in monetary policy (Vitale, 1997). In the context of this paper, such effects are of secondary importance. Alternatively, the signaling effect can be understood as a signal for the future exchange rate (Dominguez \& Frankel, 1993, p. 1356). For this purpose, sterilized interventions are quite effective, since they provide a very credible commitment by the intervening central bank. From Table 3 we can see that the intervening central bank assumes an exchange rate risk if it intervenes to support a foreign currency. It will incur losses, if the weakness of the foreign currency persists and if it abandons its intervention policy. In other words, by building up a portfolio of foreign currency assets, the domestic central bank indicates that it is not expecting a depreciation of that currency.

\section{The costs of sterilized interventions}

It is obvious that central banks in strong-currency countries can only credibly defend an exchange rate target if the costs of intervention are limited. The costs depend on three elements. ${ }^{14}$ The interest rate on the foreign assets that the central bank purchases during intervention. Since central banks usually invest their reserves in very liquid assets, the 
interest earned will be more or less identical with the foreign money market rate. The interest rate of the deposit facility (or of the short-term notes that are supplied to domestic banks). As this interest rate is used to target the domestic money market rate, it is very close to or identical with the domestic money market rate. The valuation loss or gain caused by exchange rate appreciation or depreciation of the assets that the central bank purchases during intervention.

In the following, I focus on two examples of a central bank that buys foreign exchange in order to avoid appreciation of its currency beyond the band limits. In the first case, the domestic money market rate is lower than the foreign rate, so that the central bank makes an interest-rate profit from sterilized intervention. The interest income that it obtains from its foreign assets is higher than the interest costs of the deposit facility. As long as the exchange rate remains constant, valuation profits or losses can be neglected. Such a situation existed in Japan in 2000. In the course of their interventions, the Japanese authorities have acquired dollar deposits that are remunerated at the US short-term interest rate of $6.5 \%$, while the rate on short-term yen notes is about $1 / 4 \%$.

The situation is more difficult when the domestic interest rate is higher than the foreign rate. Sterilized intervention is now associated with earnings losses for the central bank. Since such costs cannot be borne without limit, sterilized intervention again faces a budget constraint, which like the budget constraint of limited reserves, could render intervention vulnerable to speculative attacks.

The solution to this problem is, however relatively simple since the interest rate loss can be offset by a valuation profit. This requires the central bank to target a rate of depreciation of its own currency that matches the prevailing interest rate differential.

The logic of this strategy can be explained in relation to the dollar/euro rate. Let us assume that the Fed wants to prevent the euro from depreciating below a floor of 1.00 dollar per euro. With an interest rate differential of 2 percentage points in favor of the dollar, sterilized intervention brings a net interest loss for the Fed. This can be compensated if the exchange rate is adjusted over time according to the interest rate differential. For instance, with an assumed floor of 1.00 dollar per euro, the Fed would have to announce that it will adjust this limit after one year to about 1.02 dollar. ${ }^{15}$ Such a one-sided exchange rate path is credible since the Fed is always able to depreciate its own currency. Of course, the announced depreciation needs to be consistent with the central bank's broader policy objectives and with its perception of the long-run equilibrium rate.

\section{A set of bilateral arrangements for intervention policy}

Thus, for each of the G3 central banks, sterilized intervention provides an additional degree of freedom for monetary policy. As we have shown, they can target the domestic interest rate according to domestic macroeconomic priorities, while pursuing a one-sided target path for the rate of exchange of their currency vis-à-vis the two other currencies. It is also clear that each central bank can by itself do relatively little against a speculative attack that causes a depreciation of its currency. Thus, complete stabilization of the G3 currency pairs can be achieved only if each central bank is willing to pursue an intervention policy 
along the lines outlined above. Such a co-operative approach would require bilateral agreements on an exchange rate band for each currency pair. For the dollar/euro rate, for example, the ECB would defend at an upper limit of, say, 1.25 dollars per euro, while the Fed would defend a lower limit of, say, 1.00 dollar per euro.

The width of the band would take into account the conceptual difficulties of identifying equilibrium exchange rates. Both central banks are in a position to defend the respective limits even against very strong attacks. In order to minimize the costs of such interventions, the limits would have to be adjusted over time according to the prevailing short-term interest rate differential. This would generate a path for the dollar/euro exchange rate band based on the prevailing interest-rate differential. Fig. 4 simulates the path for a hypothetical arrangement starting on January 1, 2001 under the assumption of an interest rate differential of 2 percentage points in favor of the US.

Figs. 5 and 6 show what such a rule would have implied for the D-mark/dollar and the yen/dollar rates in the past. The series "exchange rate simulated by interest differential" was generated as follows. The exchange rate for 1981 was calculated by adjusting the actual exchange rate in 1980 by a factor equal to the short-term interest rate differential in 1980 . The bilateral purchasing power rate was calculated in the same way using the inflation differential in 1980. The rates for subsequent years were generated in the same way on the basis of hypothetical rates for the previous year.

The figures show that an application of the rule developed in this paper would have avoided the most serious misalignments and led to a path that is very close to a path that can be calculated from bilateral inflation differentials. As inflation rates are one of the most important determinants of nominal interest rates, this outcome is not surprising. The prominent role of the Taylor-rule shows that the cyclical position as measured by the output gap is another important determinant of short-term interest rates in the euro area (Bofinger, 1999) as well as in the United States. Thus, in the short term, the exchange rate band would fluctuate according to differences in the cyclical position of the two countries of a currency pair. In the longer term, differences in inflation differentials would prevail and lead to exchange rate paths similar to those that were predicted by the proponents of flexible exchange rates of the 1960s (Johnson, 1972). It is important to note that these exchange-rate policies do not impose any restrictions on domestic interest rate policies.

If the proposed framework is applied in a bilateral setting, it offers a way out of the "inconsistency triangle." The only modification applies to the corner solution of "fixed exchange rates." If "fixed rates" are defined as "fixed rates that are adjusted according to the interest rate differential," the "inconsistency triangle" becomes a "consistency triangle. " It allows a combination of autonomous monetary policy aimed at domestic macroeconomic stabilization, free capital mobility, and a stable exchange rate path that is determined by short-term interest-rate differentials, which are normally quite small.

\section{Open issues}

Given the complexity of international monetary arrangements, the scheme suggested in this paper does not provide a comprehensive blueprint for a trilateral arrangement between 


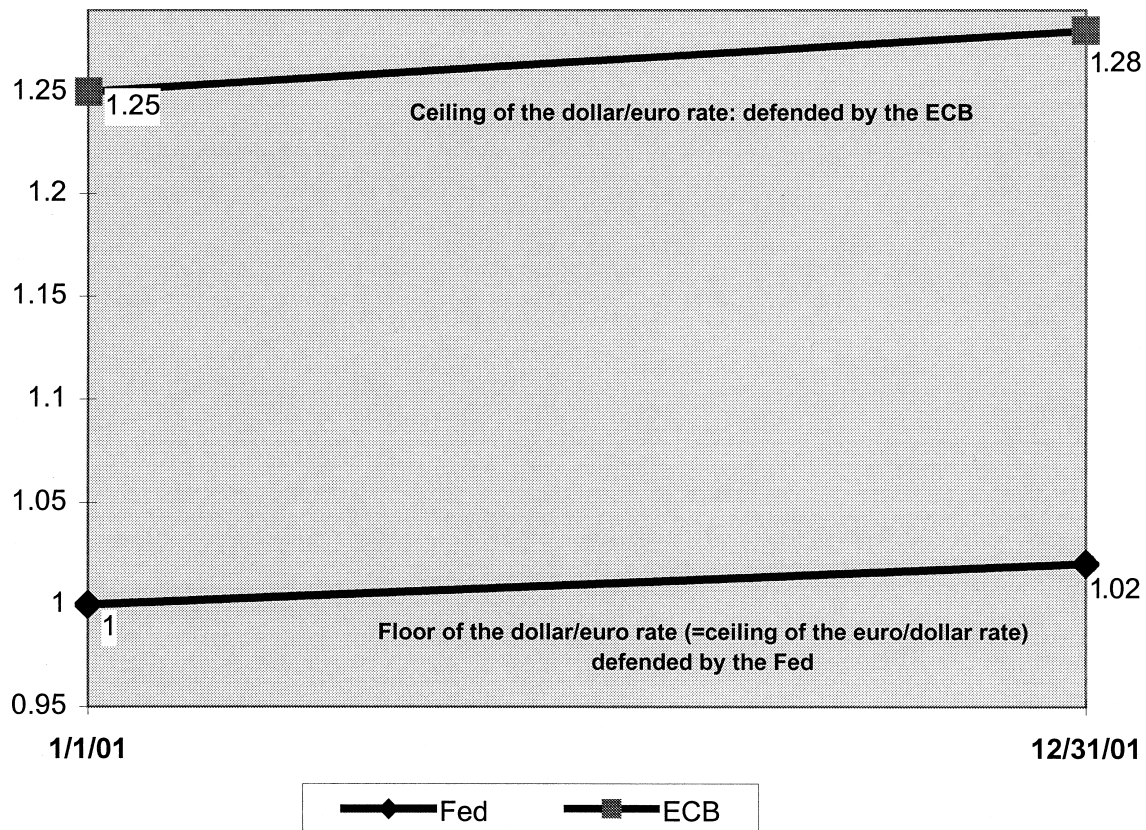

Fig. 4. Hypothetical exchange rate band for the dollar/euro rate.

the United States, Japan, and the euro area. Important issues which deserve further analysis are the following.

For any scheme that stabilizes exchange rates, agreement on nominal target rates and on band widths is essential. While many experts regard this as an almost insurmountable

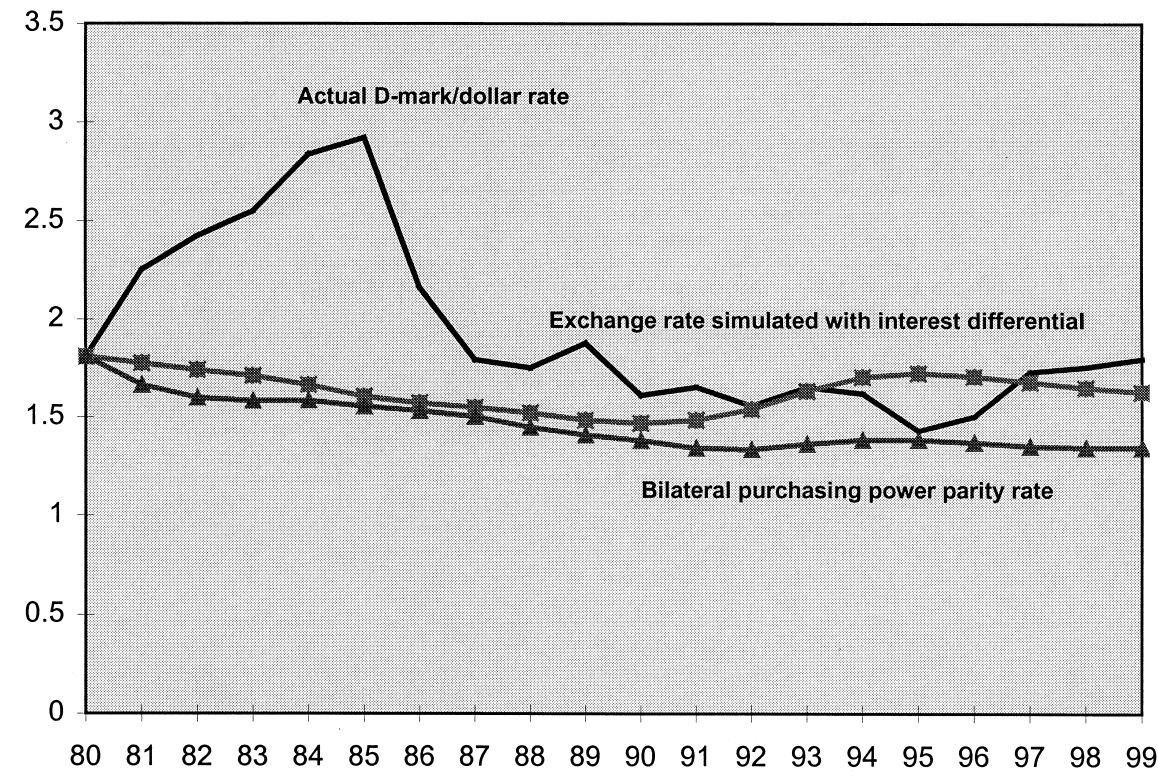

Fig. 5. Simulation of the D-mark/dollar rate by the interest rate differential. 


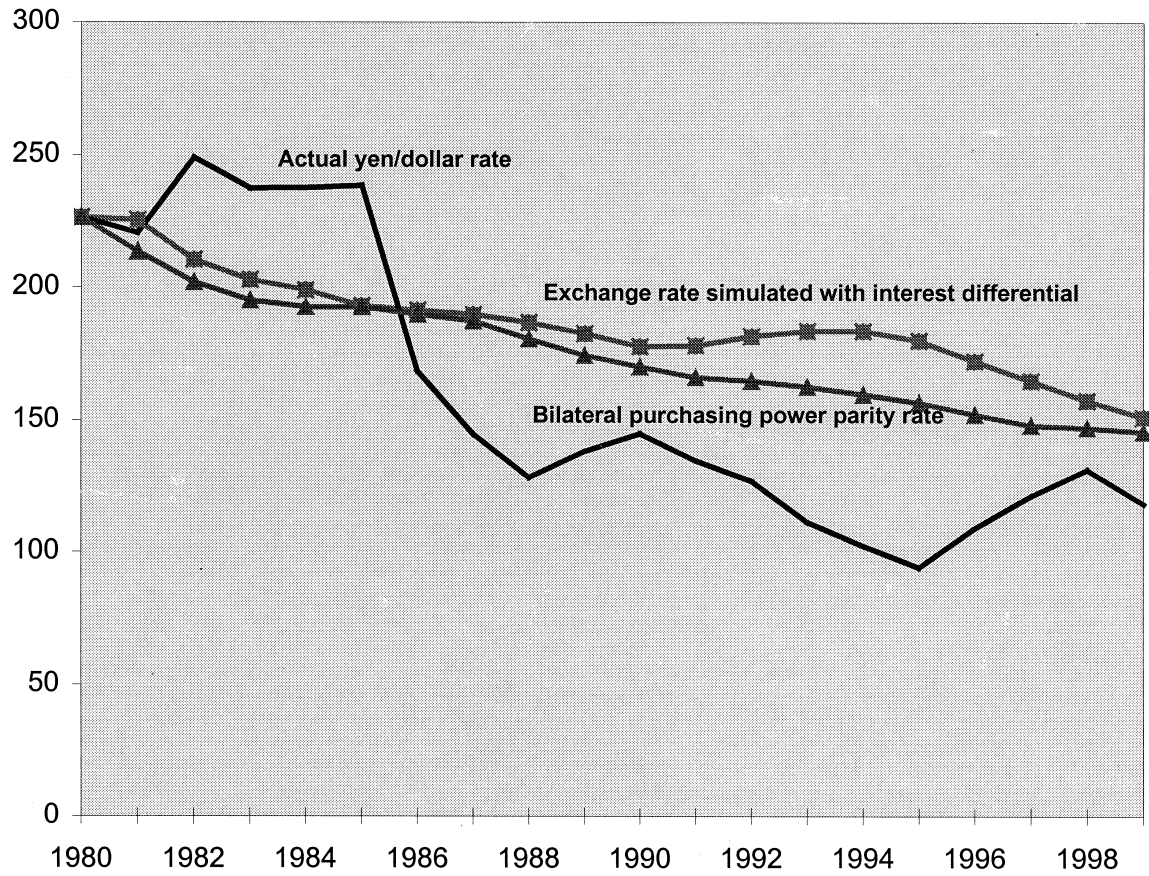

Fig. 6. Simulation of the yen/dollar rate by the interest rate differential.

obstacle (Clarida, 1999, p. 37), the experience with the European Monetary System and with the conversion rates for EMU has shown that politicians are able to agree if there is a clear political commitment to exchange rate stabilization. Nevertheless, any system of fixed or crawling exchange rates is confronted with the risk that it defends an exchange rate band that is incompatible with the macroeconomic situation in the participating countries. ${ }^{16}$ In the scheme proposed here this would imply that after defending the euro and accumulating huge euro assets, the Federal Reserve might have to lower the floor to, say 0.90 dollars per euro. Thus, the Fed would not only have made interest losses, it would also incur a valuation loss on its exchange reserves. This would require that two central banks defending an exchange rate band agree from the beginning to share the valuation profits (in the case of the ECB) and losses of a realignment. The risk of such costs have to be compared with the risks of macroeconomic costs that are created by misalignments.

An important question is whether governments in the United States, in Japan, and in the euro area countries would participate in such a co-operative scheme. From a long-term perspective, it would constitute a Pareto-improvement for all participating countries. If exchange rate misalignments can be avoided, economic risks for producers of tradable goods are reduced. This also has positive effects for workers in this sector. In contrast to the mainstream view in the literature, there is no trade-off between these efficiency gains and the macroeconomic control of the domestic economy by means of monetary policy. 
However, it should be noted that the scheme requires a high degree of mutual trust. Since the central bank with the strong currency has to support the central bank with the weak currency, it has to be confident that the currency weakness is not due to an inflationary policy stance in the partner country. As the experience of the Bretton Woods system indicates, central banks can be exposed to the risk of imported inflation. When countries share the goal of fiscal and monetary stability, this risk is rather limited. Nevertheless, the scheme would need a clearly defined and forward-looking exit clause. Otherwise, a central bank which had accumulated large foreign exchange reserves, would face huge valuation losses if it had to give up its intervention support. ${ }^{17}$ The basis for such an exit clause could be provided by the concept of inflation targeting (Schächter, 2000), which could entitle a country (or currency area) to intervention support as long as the inflation forecast is in line with a reasonable inflation target.

\section{Summary}

The paper shows that there is an additional degree of freedom in monetary and exchange rate policy that has been overlooked so far in the policy debate. The scheme that we propose allows central banks to set interest rates according to domestic macroeconomic requirements and at the same time to stabilize exchange rates along a path that is determined by the prevailing short-term interest rate differential. While each G3 central bank can set a onesided target path for its exchange rate vis-à-vis the other currencies, a bilateral agreement is needed to govern intervention within a band. A set of bilateral agreements among the G3 central banks would lead to a stable core for the international monetary order.

A main message of the paper is that economic reasons are not a general impediment for a return to more stable exchange rates. It is an open question whether politicians in the euro area, in Japan and in the United States are willing to enter a scheme which requires a high degree of trust and co-operation. But the Japanese experience in the 1990s has shown that the economic costs of misalignments can be very high (McKinnon \& Ohno, 1997). The same experience will be made by American firms if the decline of the euro vis-à-vis the dollar continues; the present level of 0.85 dollars per euro is still far away from the implicit true historical low of 0.57 dollars per euro that was reached by the euro's predecessor, the D-mark, on February 25, 1985 with a rate of 3.4525 D-mark per dollar. ${ }^{18}$ Thus, it seems worthwhile to be prepared for such a possibility and to pay more attention to coordinated exchange rate stabilization than in the past.

\section{Notes}

1. IMF (2000) diagnoses such a G3 misalignment, for example, in early 1985 and early 1995.

2. See, for instance, Eijffinger and Verhagen (1997, p. 2): "It is not likely, however, that central banks can induce a significant imbalance in investors' portfolios since the amount of official reserves is dwarfed by the daily turnover in the foreign exchange markets."

3. Net of local interdealer double counting. 
4. See Reuters (1999).

5. See Vitale (1997): "In the week 3-7 August 1992, in which particular events were not reported in the press, the average daily volume of transactions with clients of Merrill Lynch in D-marks for dollars was around \$1 billion, while their average size was about $\$ 4$ million. These figures indicate that with a relatively small market order the central bank can affect the quotes of a single market maker. Then, if this market maker has the reputation of receiving market orders form the central bank, interdealer transactions will propagate this effect on the quotes of other dealers."

6. In Japan, the Ministry of Finance is in charge of foreign exchange market intervention. Data on reserves can be obtained under www.mof.go.jp/english/e1c006.htm.

7. See Bofinger et al. (1999).

8. An alternative definition can be found in Dominguez and Frankel (1993, p. 1356): "The academic literature is predicated on the distinction between intervention operations that are sterilized and those that are allowed to affect the money supply."

9. For a detailed description, see European Central Bank (1998).

10. See Deutsche Bundesbank (1993b, p. 17).

11. For a similar view see Vitale (1997), Clarida (1999), and Schwartz (2000).

12. Dominguez (1998, p. 161) comes to the conclusion: "Overt interventions in the mid-1980s appear to have reduced exchange rate volatility ...."

13. See Dominguez and Frankel (1993, p. 1357): “. . . the average co-ordinated intervention operation in support of the dollar during the period from January 1985 to December 1988 involved $\$ 278.5$ million, while the average co-ordinated sale of dollars involved \$373.2 million."

14. A different definition of the costs of sterilized intervention is given by Eijffinger and Verhagen (1997, p. 6): "This cost can be explained by transactions costs and the fact that the central bank may incur a loss on its purchases (sales) of foreign exchange if these turn out to be unsuccessful in preventing the domestic currency from appreciating (depreciating)." It seems obvious that this definition is not adequate.

15. This follows the logic of "uncovered interest parity," according to which the difference between the expected and the actual exchange rate (divided by the spot rate) equals the difference between the home and the foreign interest rate.

16. The need for a realignment might also be necessitated by real shocks affecting one of the participating countries. In the scheme proposed here the real exchange rate would remain constant over time.

17. This happened to the Bundesbank in the 1970s after the breakdown of the Bretton Woods system.

18. The conversion rate between D-mark and euro is $1.95583 \mathrm{D}$-mark per euro.

\section{References}

Bank for International Settlements. (1999). 69th Annual report, Basle.

Bank for International Settlements. (2000). 70th Annual report, Basle.

Bofinger, P. (1999). The conduct of monetary policy by the European Central Bank according to Article 105 of 
the Treaty versus the real economy. Briefing paper for the Subcommittee on Monetary Affairs of the European Parliament. Internet: www.europarl.eu.int/dg2/ECON/EMU/EN/default.htm

Bofinger, P., Reischle, J., \& Schächter, A. (1999). The money supply process: a model for a large economy. In H. Baltensperger (Ed.), Transmissionsmechanismen der Geldpolitik (pp. 29-54). Schriften des Vereins für Socialpolitik, NF 264, Berlin.

Clarida, R. (1999). G3 exchange rate relationships: a recap of the record and a review of proposals for change. NBER Working Paper Series; No. 7344.

Deutsche Bundesbank. (1993a). Monthly Report, January, 1993.

Deutsche Bundesbank. (1993b). Monthly Report, September, 1993.

Dominguez, K. (1998). Central Bank intervention and exchange rate volatility. Journal of Money and Finance, 17, 161-190.

Dominguez, K., \& Frankel, J. (1993). Does foreign exchange intervention matter? The portfolio effect. American Economic Review, 83 (5), 1356-1367.

Eijffinger, S., \& Verhagen, W. (1997). The advantage of hiding both hands: foreign exchange intervention and private information. Mimeo.

European Central Bank. (1998). The single monetary policy in stage three. September 1998, internet: www. ecb.int

Fatum, R., \& Hutchison, M. (1999). Is sterilized intervention effective after all? An event study approach. Mimeo.

International Monetary Fund (2000). Exchange rate. Regimes in an increasingly integrated world economy. IMF Occasional Paper No. 193, Washington DC.

Isard, P., \& Faruqee, H. (Eds.). (1998). Exchange rate assessment: extensions of the macroeconomic balance approach. IMF Occasional Paper, No. 167, Washington DC.

Johnson, H. (1972). The case for flexible exchange rates 1969. In Further essays in monetary economics (pp. 198-228). Cambridge.

McKinnon, R., \& Ohno, K. (1997). Dollar and yen: resolving economic conflict between the United States and Japan. MIT Press.

Obstfeld, M., \& Rogoff, K. (1995). The mirage of fixed exchange rates. Journal of Economic Perspectives, 9 (4), 73-96.

Reuters (1999). An introduction to foreign exchange \& money markets (Reuters Financial Training Series), John Wiley \& Son Ltd.

Schwartz, A. (2000). The rise and fall of foreign exchange market intervention. NBER Working Paper Series, No. 7751.

Schächter, A. (2000). Practical issues in the adoption of inflation targeting by emerging market economies. Forthcoming as IMF Occasional Paper.

Vitale, P. (1997). Sterilized central bank intervention in the foreign exchange market. Mimeo.

Williamson, J. (1999). Crawling bands or monitoring bands: how to manage exchange rates in a world of capital mobility. Forthcoming: International Finance.

Wolf, M. (1999). Off target. Financial Times, 3 February 1999, p. 14.

Wren-Lewis, S. (1998). Exchange rates for the dollar, yen and euro. Institute for International Economics, International Economics Policy Briefs. Internet: www.iie.com/NEWSLETR/news98-3.htm 